\title{
KOMENTARZ DO PISMA SWIETEGO NOWEGO TESTAMENTU
}

Od wielu już lat próbowali polscy bibliści tłumaczyć i pisać komentarze do poszczególnych ksiąg Nowego Testamentu. Były to jednak wysilki sporadyczne i indywidualne, nie doprowadzone nigdy do końca. Dlatego polska literatura biblijna nie mogła dotąd poszczycić się tak jak to maja liczne kraje za granica, pełnym i zbiorowym komentarzem do Pisma św. Nowego Testamentu.

Brakowi temu postanowil zaradzić Katolicki Uniwersytet Lubelski, który od 1958 r. przystapił pod redakcją ks. prof. dra Eugeniusza Dąbrowskiego do wydania zbiorowo poszczególnych tomów nowego komentarza. Jako pierwsze ukazały się dwa tomy j), opracowane przez samego naczelnego redaktora nowego wydawnictwa. Tomy te omawiaja szeroko zagadnienia wstępne, głównie geografię, historię i kulturę Izraelitów.

Dobrze się stało, że te tomy ukazały się zaraz na początku (chociaż za granica wydaje się je zwykle jako ostatnie, uzupełniające tomy) ponieważ pozwola one od razu zorientować się każdemu czytelnikowi z tłem i epoką, w której powstawały księgi N. T., a tym samym ułatwia czytanie i rozumienie poszczególnych autorów, którzy choć byli pisarzami natchrionymi nie przestali przecież być ludźmi swej epoki i swego kraju.

Po tomach, omawiających zagadnienia wstępne, $w$ połowie br. ukazał się jako trzeci $\mathrm{z}$ kolei, a dziesiąty z zapowiedzianej serii komentarza, tom, wprowadzający nas od razu in medias res nowotestamentalnej problematyki. Czekaliśmy na niego z pewną niecierpliwością, chcąc zobaczyć jak właściwie będzie wyglądało konkretne opracowanie poszczegóinych tomów komentarza N. T. Autor tego tomu ${ }^{2}$ ), ks. prof. dr Stanisław E a ch Dziekan Wydz. Teol. KUL-u sprawił nam nim miłą niespodziankę. Nie jest w tej chwili moim zadaniem pisać recenzję Komentarza listu do Hebrajczyków, niemniej jednak pragnę zaznaczyć, jak to również stwierdza i sam Czcig. Autor we Wstẹpie ${ }^{3}$ ), że komentarz ten wypełnia dotkliwą

1) Por. Ks. Eugeniusz Dąbrowski, Nowy Testament na tle epoki, Poznań 1958, t. I. Geografia i Historia, t. II kultura.

2) Por. Ks. Stanisław Each, List do Hebrajczyków. Wstęp Przekład z oryginatu - Komentarz - Ekskursy, Poznań 1959.

3) Por. d. c. s. 5. 
lukę $\mathrm{w}$ polskim biblijnym piśmiennictwie. Jest on bowiem w naszej literaturze pierwszym w ogóle komentarzem tego listu. Dostarcza on również kapłanom naszym bogatego materiału do rozważań na temat kapłaństwa Chrystusowego, religii objawionej, stosunku Nowego do Starego Przymierza itp. (zob. Ekskursy s. 301-410). Stanie się na pewno milą i pożyteczną lekturą, uzupełniająca liczne nasze braki w tej dziedzinie.

Stosunkowo bardzo szybko po komentarzu do listu do Hebrajczyków ukazal się XI tom (czwarty z kolei) omawianego wydawnictwa, pióra ks. prof. dra Feliksa Gryglewicza, pt.: „Listy Katolickie". Zadziwia on nas swoimi rozmiarami (s. 522), bogactwem poruszanych myśli, a przede wszystkim obszerną i szczegółową literaturą, przytaczaną niemal przy każdej nadarzającej się okazji. Z tej racji komentarz ten może posłużyć nie tylko jako materiał do refleksji, ale również jako przewodnik po literaturze związanej z problematyką Listów Katolickich.

Wydawnictwo „Pallottinum“, które zajmuje się drukiem nowego komentarza do N. Testamentu, zapowiedziało ukazanie się z początkiem grudnia br. XII tomu tegoż komentarza, pióra O. dra Augustyna J ankowskiego OSB, pt.: „Apokalipsa“. Ze względu na ciekawą problematyke tej księgi, oraz na jej charakter proroczy z niecierpliwością oczekujemy ukazania się tego dzieła. Druk „Apokalipsy" jest już na ukończeniu. Dalszych tomów należy się spodziewać w przyszłym roku.

Kraków

KS. STANISEAW GRZYBEK 